\title{
Physical Growth and Nutritional Status of the Lambadi Children of Andhra Pradesh
}

\author{
S. Yaseen Saheb and M. Rajendra Prasad \\ Anthropological Survey of India, Southern Regional Center, Manav Bhavan, \\ Mysore 570 026, Karnataka, India
}

KEYWORDS Health. Physical growth. Nutritional Status. Tribe

\begin{abstract}
The Lambadi is one of the largest scheduled tribes in Andhra Pradesh. Prior to1976, they were notified as a denotified tribe. They live in exclusive settlements called 'tanda', maintaining their cultural and ethnic identity. Study on growth and development of the Lambadi children was carried out in Nalgonda district in Telangana region of Andhra Pradesh, to assess the pattern of growth and development of the children aged 6 to 10 years of both sexes in terms of anthropometric characters, i.e., Weight and Stature. The Body Mass Index (BMI), Weight deficit for age and Height deficit for age classification to evaluate the extent of malnutrition prevalent among the Lambadi children. The data were collected from 45 'tandas' spread over 12 revenue mandals, covering 417 unrelated healthy Lambadi children comprising 208 boys and 209 girls, who's parents' subsistence economy is based on agriculture and animal husbandry. Statistical constants were calculated for each anthropometric trait for the interpretation of growth and nutritional status of the Lambadi children.
\end{abstract}

\section{INTRODUCTION}

The growth and development of human physique is considered an important area of research as it provides determinants of Nation's health. Growth and development of children concern with physical growth, mental and social development and personality of a child. Many studies indicate that the pattern of physical growth and development, though genetically determined, is strongly influenced by socioeconomic and nutritional status. Studies in human growth and development received least attention in our country. There is a dearth of published material on growth and development of children of Scheduled tribes of Andhra Pradesh except the studies of Rao and Busi on Jatapu (1994), Savara (1995), Chenchu (1996), Koya Dora (1997) and Porja (1999).

\section{AREA AND PEOPLE}

Andhra Pradesh comprises three cultural regions namely, coastal Andhra, Telangana and Rayalseema and has different historical backgrounds. The Nalgonda district in Telangana region is perpetually drought prone and it lies between $16^{\circ} 25^{\prime}$ and $17^{\circ} 50^{\prime}$ North latitudes and $78^{\circ} 40^{\prime}$ and $80^{\circ} 50^{\prime}$ Eastern longitudes covering an area of 14,240.00 sq km. The district is divided into Nalgonda, Bhonger, Miryalaguda and Suryapet revenue divisions, comprising 59
Mandals and 8 towns. The climate is very dry. The maximum temperature in summer is about $47^{\circ} \mathrm{C}$. The average rainfall is $772 \mathrm{~mm}$. Most of the Lambadi tandas covered in present study falls in Damercherla, Devarakonda and Chandampeta mandals.

The Lambadi are known by different names, Banjara, Banjari, Lambada and Lambani in Telangana region and Sugali and Sukali in Rayalaseema region of Andhra Pradesh. The Lambadi are one of the largest scheduled tribes, predominantly inhabiting the nine Telangana districts and they are sparsely distributed in Guntur, Krishna, and West Godavari and Nellore districts of coastal Andhra Pradesh. Generally they live in exclusive settlements called 'tandas', maintaining their cultural affinities and ethnic identity. Various historical records suggest that they originally hail from northern parts of the country, especially from the Marwar region of Rajasthan. They migrated from northern to southern India as carriers of good grains and merchandise on pack bullocks along with the invading Mughal army (Census of India 1961).

The Lambadi present a complete picture of transition from pastoral nomads to settled peasants in recent times. They gave up their traditional occupation of merchandise on pack animals, after the advent of modern methods of transportation. The Lambadi are derived from the Charan group of Banjara. They speak Lambadi, a corrupt form of Hindustani and Marwari, with a 
mixture of local language. According to 1961 census, Lambani or Lambadi was spoken by 6 , 79, 363 persons, of whom 3, 41, 204 are bilinguals. Among the bilinguals, Telugu was spoken as a second language by $2,65,378$ persons, Urdu by 13, 545 persons and 8, 104 persons spoke other languages. The Lambadi are strong and versatile people, with medium stature, mesocephalic head and light brown to dark reddish brown skin colour (Basu 1999). The traditional dress of men comprises of dhoti, short trousers and gaudy turbans. Their women folk wear langa of coarse cotton, prints of rich embroidery with many folds at the waist.

The Lambadi are divided into five phratries (Goth) namely, Rathod, Chouhan, Pamar, Vadithya and Banoth. These phratries are further subdivided into a number of patrilineal kingroups, called padas or jat (clan) in their language. The Rathod phratry consists of 27 clans, while Vadithya phratry has 52 clans, Chouhan has 6 clans, Pamar 12 clans and Banoth 13 clans; The Rathod is also known as Bhukya, Vadhithya is also called Jadhav and Banoth as Ade. Each phratry is an exogamous unit and one has to marry outside of the phratry. Clan is patrilineal and the clan name is used as the prefix to the name of an individual.

The Lambadi have their servicing communities. There are traditional musicians and bards to the Lambadi called Dappan. The Dappan depend mainly on the gifts presented by the Lambadi on ceremonial and ritual occasions and also work as manual labourers. There are three divisions among the Dappan namely Bhat, Dhadi and Dhalia. The Bhat and Dhadi sing songs on Lambadi family history by playing musical instruments called jange and Kinjri, during marriage ceremonies. The Dhalia or Dapadiya play dappu on ceremonial occation. There are traditional barbers to the Lambadi called Nhavi. In addition to these subdivisions, there is another endogamous group called Sonar Lambadi, who manufactures silver and gold ornaments. All the above subdivisions are endogamous groups of the Lambadi tribe. These groups have adopted the clan organization of the Lambadi, but inter group marriages are strictly prohibited. All these subdivisions are considered inferior in social status to the main Lambadi community.

Food and Food Habits: The staple diet of the Lambadi consists of ragi, jowar and rice. With jowar and ragi flour they prepare food item called "sangati". They take 'sangati' mixing with butter milk and use chutney prepared out of chilies or groundnut as side dish. Most important diet of the community is jowar roti, prepared out of jowar flour. The roti are baked without any oil or ghee on the frying pan or on burning charcoal. They prefer to eat roti along with mutton or chicken curry. Another important diet for them is 'karappodi powder, which is prepared with fried dry chilies, garlic, Dania (coriander seeds) and little salt. This can be kept for two to three weeks. Whenever curry is not prepared, they take 'karappodi' and mix with rice adding cooking oil or ghee for taste. Children also cherish this rice because of its good taste. In the morning, they consume 'sangati' with butter milk or chutney before going to work. In the after-noon they take rice with dal or rasam. During nights they usually consume jowar roti with vegetable curry or nonvegetarian curry of chicken, mutton, wild cat, peacock, rabbit etc. But they do not consume beef and pork. Normally children take food three times a day. While serving food, priority is given to children especially male children and only left over is consumed by elders.

The Lambadi households take non-vegetarian food. Changes have taken place in their consumption of pulses as well as staple food. Consumption of red gram and horse gram (Kulti) is reported among $32.95 \%$ of households, whereas $48.1 \%$ of households consume red gram and chana (Bengal gram), 17.72\% of households consume red gram and $3.42 \%$ moong dal. In earlier days their children used to get more jowar, maize and ragi food items. Now $10.86 \%$ of household abstain from jowar, maize and ragi, but they consume only rice. Only $5.08 \%$ of households take ragi and very few households started wheat consumption. Consumption of rice is common in all the households, while $32.91 \%$ of the households take wheat and maize, while $44.82 \%$ of households consume products of jowar and maize. Regular consumption of milk is reported among $22.92 \%$ of children. Nearly $40.50 \%$ of children get sufficient food either at school or residence. While $39.25 \%$ of them get moderate quantity of food and only $20.25 \%$ children get insufficient food.

Health and Hygiene: About 41.99 lacks of tribal population in Andhra Pradesh do not have a clear perception of health; illness and hygiene (Census1991).Their perception of health and illness are based on performance orientation. 
According to World Health Organization, health is defined as "a state of complete physical, mental and social well being and not merely the absence of disease or infirmity. Hygiene means the care of body and its individual parts" (WHO 1995). But health status is a product of the interaction between socio-cultural practices, bio-genetic characteristics and environmental conditions.

The Lambadi of Nalgonda district maintains their 'tanda' hygienically. Each house is a separate structure by itself and houses are built side by side in two parallel rows at the outskirts of the main village, even after leaving their nomadism. The consideration of health, convenience of grazing fields and housing of their cattle and immunity from epidemics is other factors in their choice of residence. Most of the houses have pits to decompose household waste and cow dung. The front yards of the houses are swept daily and water mixed with cow dung is sprinkled at least once in two days. In the present study, 58 percent of the houses are maintained neatly. The traditional hut called "Qupada" has changed its oblong shape like the thatched hut constructed by the caste population near the village. Economically better off Lambadis have built pucca houses with proper ventilation (43.04\%) and have modern amenities, with double room houses $(54.43 \%)$, separate kitchen $(88.61 \%)$ and 'veranda'. Even though 43.04 percent of houses are not having proper sunlight and 51.90 percent of houses do not have good ventilation. Out of the 45 tandas surveyed, only two tandas (4.5\%) have drainage facilities. Most of the Lambadi $(93.67 \%)$ are not conscious of the need to have latrines. They are very conscious to clean their teeth. They do not eat in the morning without cleaning their mouth. Educated children and enlightened persons clean their teeth with brush and tooth paste. Uneducated persons use twigs of neem tree or charcoal powder. Maximum number of children have yellowish teeth $(44.64 \%)$ due to the high fluorine mineral content in their drinking water. Chewing pan supari is also one of the causes for the prevalence of yellowish teeth among the elders. It is observed among the people residing in Meriyalaguda, Damarcherla and Suryapet, where river water is available for drinking. In taking bath and changing the dress, the Lambadi are not particular. Very few Lambadi take bath daily. The elderly women who wear traditional dress, kanchidi (blouse) phaita and ghagra (short saree) change their dress once in
15 days after taking bath. Educated women and men take bath with soap regularly and change their cloths once in two days. Their children are also given bath with soap twice a day. This depends on the availability of water in the tandas. It is observed that in all tandas, water is available from well and hand bore wells. Fifty four percent households are utilizing hand bore water, 30.38 percent well water, 10.13 percent have both tap and bore water and 2.53 percent have wells and bore water facilities. Considering the above mentioned hygienic conditions the personal cleanliness of the children score $55.56 \%$ satisfactory health, $30.51 \%$ good health and only $13.93 \%$ are of poor health. In general the children appear neat and clean when compared to other tribal children in Andhra Pradesh.

The Lambadi are very keen to clean their utensils. The present study reveals that 94.94 percent households clean their utensils neatly and keep them in proper places. Only in $5.07 \%$ of households, the utensils are not properly cleaned and stored. Though the utensils are bright and sparkling, the cleaning process is not hygienic. Most of the Lambadi take their daily used utensils such as stainless steel plates, tumblers; cooking utensils etc. to the bore well and apply sticky mud and sand available near the bore well for cleaning purpose. Some use detergent cakes as cleaning agents. These are most unhygienic and unhealthy practice. Sometimes this process of cleaning near the bore wells is contaminating drinking water and hazardous to children's health.

\section{MATERIAL AND METHODS}

Bio-cultural data on family size, type of family, occupation, literacy levels of the parents, income, birth order of the child, relationship of spouse before marriage, date of birth of children were collected from 417 households of school children aged between 6 to 10 years. Information on health and hygiene, food habits, etc, was collected from 200 households from 45 tandas spread over 12 mandals. The children aged 6 years to 6 years 11 months are considered as 6 years. In every age group a minimum of 40 subjects of each sex were selected. Anthropometric measurements viz. weight and stature was collected following standard techniques (Weiner and Lourie 1969 and Singh and Bhasin 1968). Each Lambadi child was examined for the clinical signs of nutrition deficiency disorders: Pellagrous dermatitis 
(Pigmentation of skin), Angular Stomatitis, Phrynoderma (Dry scaly skin), Kwashiorkor (Discoloured hair), Pale Conjunctiva, Night Blindness, Spongy bleeding gums and Dental fluorosis (Yellowish teeth). The distance curves are drawn for anthropometric traits based on the mean values at different ages. The velocity curves are drawn based on the values of the relative rate of growth between successive ages. Body mass index (BMI), calculated by dividing weight in kilograms by the square of height in meters. The results were grouped into different nutritional grades based on Body Mass Index as suggested by WHO (2000). The Lambadi children weight data were subjected to weight deficit for age classification of Gomez et al (1956) using NCHS standards for each age and sex; and grouped into different grades of under-nutrition. The data on height of the Lambadi children were subjected to height deficit classification for age into different categories of stunting, using NCHS standards.

\section{RESULTSANDDISCUSSION}

\section{Somatoscopic Observations and Health Status}

The Lambadi children have been grouped into different-arbitrary health status categories. The child's health has been scored by physical observations of the child's personal physique, hygiene and general health. If the child is not suffering from any ailments and nutritional deficiency signs, he/she is placed in good health. On the contrary if the child is suffering from major nutritional disorders, then child is placed under weak health. A child with normal physique is treated as having satisfactory health table 1 . Majority of the boys are found to have satisfactory health and the frequency varies from $67.7 \%$ at 6 years, to $71.4 \%$ at 7 years, $63.6 \%$ at 8 years, $61.0 \%$ at 9 years and $66.0 \%$ at 10 years. Whereas the frequency of girls having satisfactory health condition varied from $52.3 \%$ at 6 years to $66.7 \%$ at 7 years, $73.9 \%$ at 8 years, $40 \%$ at 9 years and $41.2 \%$ at 10 years. The frequency of boys having weak health varies from $6.0 \%$ at 10 years to $19.0 \% 7$ years, while $9.7 \%$ of boys in 6 years, $9.1 \%$ at 8 years and $17.1 \%$ at 9 years are observed to be weak and anemic. Low frequencies of weak health are observed among girls of 8 years $(2.2 \%)$, 9 years $(5.0 \%)$ and 10 years $(2.9 \%)$, while higher frequency of weak health are recorded at 6 years $(18.2 \%)$ and at 7 years (13.3\%). Girls having weak
Table 1: General health among Lambadi children

\begin{tabular}{|c|c|c|c|c|c|}
\hline \multirow{2}{*}{$\begin{array}{l}\text { S. } \\
\text { No. }\end{array}$} & \multirow{2}{*}{$\begin{array}{l}\text { Health } \\
\text { Status }\end{array}$} & \multicolumn{2}{|l|}{ Male } & \multicolumn{2}{|l|}{ Female } \\
\hline & & Frequency & $\%$ & Frequency & $\%$ \\
\hline \multirow[t]{4}{*}{6} & Weak & 3 & 9.7 & 8 & 18.2 \\
\hline & Satisfactory & 21 & 67.7 & 23 & 52.3 \\
\hline & Good & 7 & 22.6 & 13 & 29.5 \\
\hline & Very Good & - & - & - & - \\
\hline \multirow[t]{4}{*}{7} & Weak & 8 & 19.0 & 6 & 13.3 \\
\hline & Satisfactory & 30 & 71.4 & 30 & 66.7 \\
\hline & Good & 4 & 9.5 & 9 & 20.0 \\
\hline & Very Good & - & - & - & - \\
\hline \multirow[t]{4}{*}{8} & Weak & 4 & 9.1 & 1 & 2.2 \\
\hline & Satisfactory & 28 & 63.6 & 34 & 73.9 \\
\hline & Good & 12 & 27.3 & 10 & 21.7 \\
\hline & Very Good & - & - & 1 & 2.2 \\
\hline \multirow[t]{4}{*}{9} & Weak & 7 & 17.1 & 2 & 5.0 \\
\hline & Satisfactory & 25 & 61.0 & 16 & 40.0 \\
\hline & Good & 9 & 22.0 & 22 & 55.0 \\
\hline & Very Good & - & - & - & - \\
\hline \multirow[t]{4}{*}{10} & Weak & 3 & 6.0 & 1 & 2.9 \\
\hline & Satisfactory & 33 & 66.0 & 14 & 41.2 \\
\hline & Good & 14 & 28.0 & 19 & 55.9 \\
\hline & Very Good & - & - & - & - \\
\hline
\end{tabular}

health are found to be more in 6 years and 7 years, while boys with good health are found to be in higher proportion at 10 years $(28 \%)$ followed by at 8 years $(27.3 \%), 6$ years $(22.6 \%)$ and 9 years $(22.0 \%)$. Girls having good health record higher frequencies at 10 years $(55.9 \%)$, followed by at 9 years $(55.0 \%), 6$ years $(29.5 \%), 8$ years $(21.7 \%)$ and at 7 years $(20.0 \%)$. In general, the health status of girls is better than that of boys, with fluctuating frequencies in different age groups. Only one girl aged 8 years has been classified as having very good health.

\section{Clinical Signs and Nutritional Deficiency}

The prevalence of different types of nutritional deficiency signs have been recorded following Kaul and Nyamongo (1990) among the Lambadi children shown in table 2. Angular stomatitis occurs due to the deficiency of Vitamin B. The present investigation among the Lambadi children indicates that $10.58 \%$ of boys and $7.18 \%$ of girls are observed to have this deficiency. Angular stomatitis occurs at a higher rate among the boys of all ages than among the girls. The frequency ranges from $12.0 \%$ to $17.1 \%$ among boys, while it ranges from $2.9 \%$ to $10.0 \%$ in girls.

Dry scaly skin occurs due to Vitamin-A deficiency. The prevalence of dry scaly skin is low among girls $(0.96 \%)$ than that of boys $(1.44 \%)$. Dry scaly skin is observed in low frequency among 8 and 10 year old boys; and 8 


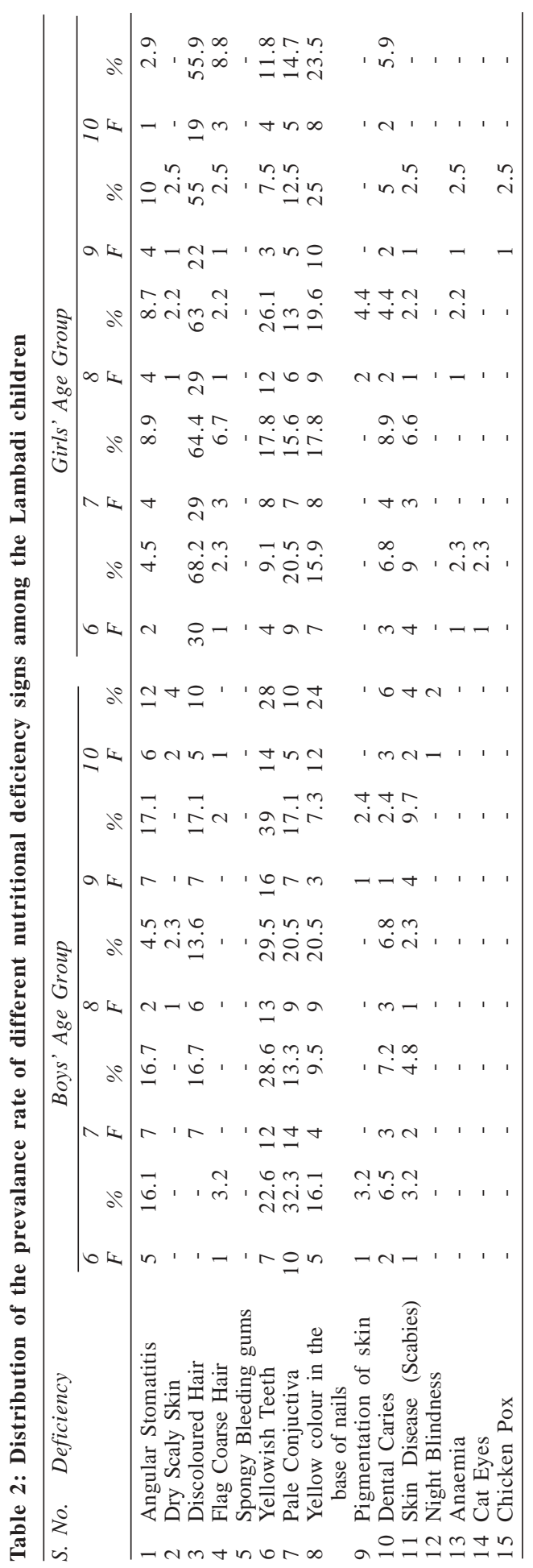

and 9 year old girls. The prevalence of discoloured hair among Lambadi children reveals that this condition is more frequent among girls $(61.72 \%)$ than in boys $(12.02 \%)$. A higher proportion of discoloured hair has been noticed among girls in all age groups, while it occurs among the boys of 7 to 10 years with lower proportions. Flag or coarse hair is prevalent among $4.31 \%$ of girls and $0.96 \%$ of boys. The occurrence of coarse hair is at higher rate among 7 and 10 year old girls (table-2).

All the 417 Lambadi children have been screened for spongy bleeding gums, a sign for the deficiency of vitamin C; but none of them are afflicted with this clinical sign. Yellowish teeth with mottled enamel occur at a higher proportion among boys $(29.8 \%)$ than among the girls $(14.83 \%)$. The prevalence of yellowish teeth or fluorosis is evenly distributed in all the age groups of boys, with differing proportions, while its occurrence is high among the girls of 7 and 8 years age groups. Pale conjunctiva occurs at a higher frequency (21.63\%) among boys than in girls $(15.31 \%)$. The incidence of pale conjunctiva is high among boys and girls of younger age groups. The frequency declines as age advances in both the sexes (Table 2).

The occurrence of yellow colour in the base of the nails is in higher proportions among girls $(20.10 \%)$ than in boys $(15.87 \%)$. This condition is observed in all the age groups of Lambadi children, with differing magnitudes from younger to older age groups. The pigmentation of skin (niacin deficiency) is reported only in two cases, which is a negligible frequency $(0.48 \%)$.

Dental caries have been observed in an equal number of boys and girls, though the frequency is slightly higher among girls (6.22\%) than that of boys $(5.77 \%)$. Caries have been reported in both deciduous and permanent teeth of the Lambadi children, which are related to their dietary habits and the effect of the food consumed. Skin diseases like scabies have been noticed in both boys and girls of the present study. The prevalence rate is more or less same in boys and girls. In the whole sample, only a 10 year old boy is having night vision deficiency, while a 9 year old girl is having cat eye. A few girls are observed to be in anaemic condition due to malnutrition.

\section{The Anthropometric Measurements and Physical Growth and Nutritional Status}

Weight: The statistical constants for weight 
of the Lambadi children are presented in table 3. The Lambadi children show a steady increase in weight from 6 years to 10 years in their mean values. The mean weight for boys and girls at 6 years is $18.26 \mathrm{~kg}$ and $17.72 \mathrm{~kg}$ respectively indicating that boys are slightly heavier than girls. The mean values of boys at 10 years $(24.77 \mathrm{~kg})$ are lower by $1.79 \mathrm{~kg}$ than girls $(26.56 \mathrm{~kg})$ at the same age. The total gain in mean weight for boys is $6.52 \mathrm{~kg}$ between 6 to 10 years, which is lesser than that of girls $(8.84 \mathrm{~kg})$ by $2.33 \mathrm{~kg}$ for the same period. The mean values of boys at 7,8 and 9 years show slightly higher values than the mean values of girls at their respective ages, whereas the mean values of boys at 10 years show a reverse trend. The variability of mean weights increased steadily with advanced age for both sexes, but the difference is insignificant. The value of variance for boys range from 4.93 to 7.38 ; while the values for girls range from 4.52 to 10.79 . The highest variance value for both boys and girls is observed at 9 years. The mean weight of Indian boys at 6 years $(16.3 \mathrm{~kg}$ ) of ICMR (1972) study show much lower value by $1.96 \mathrm{~kg}$ than the Lambadi boys. Likewise the Lambadi girls of 6 years also register slightly higher mean body weight by $1.72 \mathrm{~kg}$ than the Indian girls $(16.0 \mathrm{~kg})$. The mean body weight of Lambadi boys aged 10 years showed higher mean value, than that of the Indian boys (23.5 kg) by $1.27 \mathrm{~kg}$ (ICMR 1972). The mean body weight of Lambadi girls aged 10 years recorded significantly higher mean value, by $2.96 \mathrm{~kg}$ than the results reported by ICMR (1972) for Indian girls $(23.6 \mathrm{~kg})$.

The distance growth curves for body weight show the distribution of mean weight plotted against age of the Lambadi boys and girls (Fig. $1)$. The distance curves for body weight show steady rise from 6 to 10 years for both sexes. In older years the growth curve of girls over takes the boys at the age of 10 years, with increase in mean values, taking an upward momentum than that of boys. On the whole, the distance curves of Lambadi children for body weight resemble to the growth curves observed in other populations, with little variation.

The weight velocity curves are drawn taking mean differences in weights between successive incremental years of boys and girls (Fig. 2). The velocity curve for weight reaches the highest peak points at the $10^{\text {th }}$ increment year for both sexes, where the Lambadi children record their maximum mean weights. Both boys and girls present a downward path in their velocity curves at $9^{\text {th }}$ increment year, indicating a loss in their body weight, but there after the velocity curves take progressive upward momentum. The upward path in the velocity curve of boys is marginally lower to that of girls, reflecting a decline in the velocity for boys compared to that of girls. The velocity curves of boys and girls show divergent paths in the upward course. The gulf between the velocity curves of both sexes show significant sexual dimorphism in mean body weights, indicating a spurt in growth rate of girls at 10 years.

Stature: The statistical constants of stature of Lambadi children are presented in table 3 . Stature increases with the age of the children is a natural phenomenon. A general increase in height for both boys and girls is observed, boys being slightly taller than girls up to the age of 9 years, while girls take a slight lead value at 10 years. The mean stature value of boys at 6 years $(116.42$ $\mathrm{cm})$ is slightly higher $(0.77 \mathrm{~cm})$ than the mean value of girls $(115.65 \mathrm{~cm})$. The mean stature value of girls at 10 years $(134.14 \mathrm{~cm})$ is $1.10 \mathrm{~cm}$ higher than that of boys $(133.04 \mathrm{~cm})$. The total gain in stature from 6 years to 10 years is $16.62 \mathrm{~cm}$ in boys and $18.49 \mathrm{~cm}$ in girls. The variance is the

Table 3 : Statistical constants of some anthropometric measurements of the Lambadi children

\begin{tabular}{|c|c|c|c|c|c|}
\hline \multirow{2}{*}{$\begin{array}{l}\text { Age } \\
\text { group } \\
\text { (years) }\end{array}$} & \multirow{2}{*}{$\begin{array}{r}\text { Statistical } \\
\text { constants }\end{array}$} & \multicolumn{2}{|c|}{ Weight (kg.) } & \multicolumn{2}{|c|}{ Stature $(\mathrm{cms})$} \\
\hline & & Male & Female & Male & Female \\
\hline \multirow[t]{5}{*}{6} & $\mathrm{~N}$ & 31 & 44 & 31 & 44 \\
\hline & Mean & 18.26 & 17.72 & 116.42 & 115.65 \\
\hline & $\mathrm{SD}$ & 2.22 & 3.04 & 6.17 & 4.3 \\
\hline & SE Mean & 0.4 & 0.46 & 1.11 & 0.65 \\
\hline & Variance & 4.93 & 9.25 & 38.11 & 18.45 \\
\hline \multirow[t]{5}{*}{7} & $\mathrm{~N}$ & 42 & 45 & 42 & 45 \\
\hline & Mean & 18.85 & 18.78 & 118.73 & 117.91 \\
\hline & SD & 2.14 & 2.13 & 4.17 & 4.9 \\
\hline & SE Mean & 0.33 & 0.32 & 0.64 & 0.73 \\
\hline & Variance & 4.59 & 4.52 & 17.41 & 23.98 \\
\hline \multirow[t]{5}{*}{8} & $\mathrm{~N}$ & 44 & 46 & 44 & 46 \\
\hline & Mean & 21.63 & 21.34 & 125.36 & 122.21 \\
\hline & SD & 2.57 & 2.92 & 6.38 & 4.84 \\
\hline & SE Mean & 0.39 & 0.43 & 0.96 & 0.71 \\
\hline & Variance & 6.64 & 8.5 & 40.66 & 23.42 \\
\hline \multirow[t]{5}{*}{9} & $\mathrm{~N}$ & 41 & 40 & 41 & 40 \\
\hline & Mean & 22.13 & 21.93 & 127.3 & 124.58 \\
\hline & SD & 2.9 & 3.29 & 6.06 & 6.54 \\
\hline & SE Mean & 0.45 & 0.52 & 0.95 & 1.03 \\
\hline & Variance & 8.43 & 10.79 & 36.76 & 42.81 \\
\hline \multirow[t]{5}{*}{10} & $\mathrm{~N}$ & 50 & 34 & 50 & 34 \\
\hline & Mean & 24.77 & 26.56 & 133.04 & 134.14 \\
\hline & SD & 2.72 & 2.92 & 4.48 & 4.72 \\
\hline & SE Mean & 0.38 & 0.5 & 0.63 & 0.81 \\
\hline & Variance & 7.38 & 8.5 & 20.09 & 22.26 \\
\hline
\end{tabular}




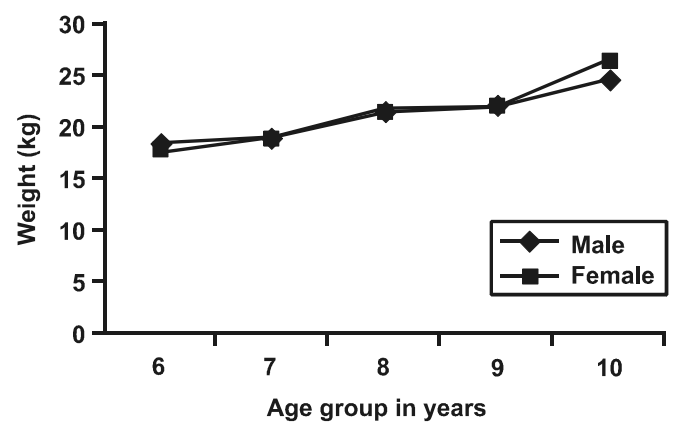

Fig. 1. Distance curve for Weight of the Lambadi Children

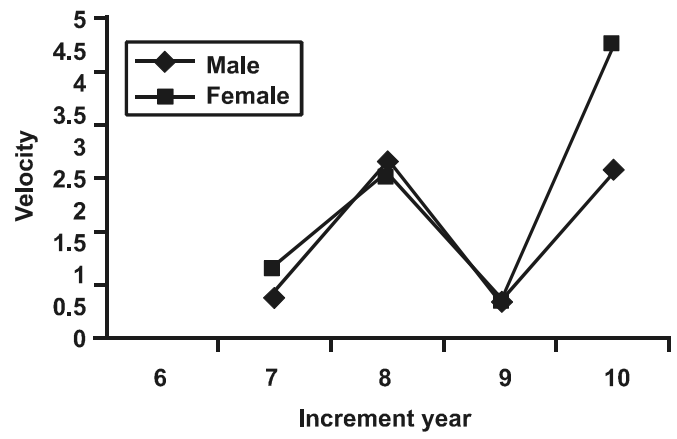

Fig. 2. Velocity curve for Weight of the Lambadi Children

lowest at 7 years for boys and the highest value is at 8 years, while the corresponding values are 18.45 at 6 years and 42.81 at 9 years for girls. The mean stature value of Indian boys $(108.5 \mathrm{~cm})$ and Indian girls $(107.4 \mathrm{~cm})$ of 6 years of age are comparatively lower by $7.92 \mathrm{~cm}$ and $8.25 \mathrm{~cm}$ respectively than that of Lambadi boys (116.42 $\mathrm{cm})$ and girls $(115.65 \mathrm{~cm})$. The mean stature value of Lambadi boys $(133.04 \mathrm{~cm})$ and girls $(134.14 \mathrm{~cm})$ register significantly higher stature value than the Indian boys at 9 years $(124.4 \mathrm{~cm})$ and Indian girls $(128.4 \mathrm{~cm})$ at 10 years of age (ICMR 1972).

The distance growth curves for stature of the Lambadi children are plotted in Figure 3, taking the mean stature against age of boys and girls separately. The distribution of growth curves for boys and girls assume the familiar growth curves observed in human populations, showing steady progressive course with increasing age. The growth curve of girls shows progressive path and over takes the growth curve of boys at the age of 10 years. The growth velocity curves of stature

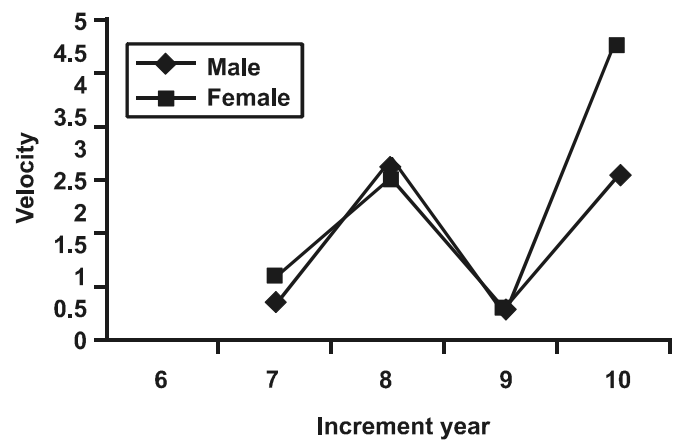

Fig. 3. Distance curve for Stature of the Lambadi Children

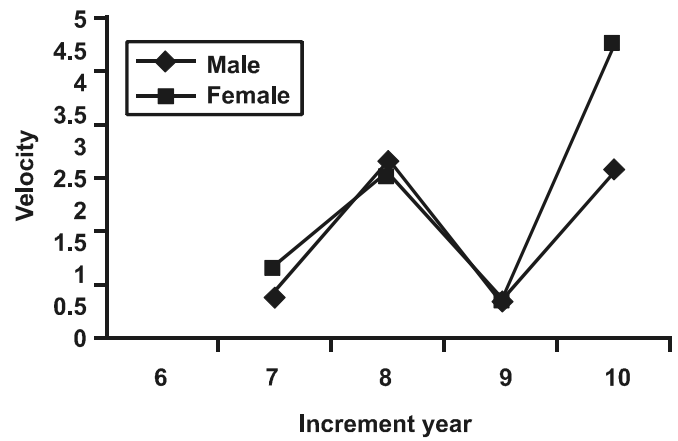

Fig. 4. Velocity curve for Stature of the Lambadi Children

(Fig. 4) of the Lambadi boys present higher growth velocity in stature than that of girls at $8^{\text {th }}$ increment year, but the velocity curves take downward course in both sexes at $9^{\text {th }}$ increment year, with lower intensities. The velocity curve of girls show a steep rise in intensity in-between 9 and 10 years, compared to that of boys. The gap between the velocity curves at various incremental years of boys and girls indicate sex difference in growth velocities.

Growth Rate per Annum: The annual growth rate in weight of Lambadi children showed a steep rise in value from 7 years to 8 years $(11.52 \mathrm{~kg}$ in boys and $7.65 \mathrm{~kg}$ in girls). The growth rate per annum is low in both sexes at $9^{\text {th }}$ increment year (Table 4). There is steep increase in body weight at 10 years in both sexes, but girls out score the boys, with a gain of $9.24 \mathrm{~kg}$ per annum. The annual growth rate in stature is $1.98 \mathrm{~cm}$ for boys and 1.95 $\mathrm{cm}$ for girls at $7^{\text {th }}$ increment year, with accelerated values at $8^{\text {th }}$ increment year for both the sexes. There is deceleration in growth rate at the 
Table 4: Absolute growth rate per annum among the Lambadi male and female children

\begin{tabular}{lccccc}
\hline Increment & \multicolumn{2}{c}{ Male Children } & & \multicolumn{2}{c}{ Female Children } \\
\cline { 2 - 3 } \cline { 6 - 6 } & $\begin{array}{c}\text { Weight } \\
(\mathrm{kgs})\end{array}$ & $\begin{array}{c}\text { Stature } \\
(\mathrm{cms})\end{array}$ & & $\begin{array}{c}\text { Weight } \\
(\mathrm{kgs})\end{array}$ & $\begin{array}{c}\text { Stature } \\
(\mathrm{cms})\end{array}$ \\
\hline $7^{\text {th }}$ & 3.23 & 1.98 & & 5.98 & 1.95 \\
$8^{\text {th }}$ & 14.75 & 5.58 & & 13.63 & 3.65 \\
$9^{\text {th }}$ & 2.31 & 1.55 & & 2.72 & 1.94 \\
$10^{\text {th }}$ & 11.93 & 4.51 & & 21.17 & 7.67 \\
\hline
\end{tabular}

subsequent increment year for Lambadi children in stature. The growth rate is significantly higher among girls at 10 years than that of boys (Table 4).

Body Mass Index (BMI): The body mass index for Lambadi children is calculated by dividing weight in kilograms by the square of stature in meters. Based on the body mass index, the Lambadi children are grouped into different

Table 5: Frequency distribution of body mass indices among the Lambadi children

\begin{tabular}{|c|c|c|c|c|c|}
\hline Sex & $\begin{array}{l}\text { Age group } \\
\text { ( in years) }\end{array}$ & BMI-Classification & Frequency & Percent & Category \\
\hline \multirow{23}{*}{ Male } & \multirow{5}{*}{6} & $<16$ & 3 & 16.13 & CED IIII \\
\hline & & $16.00-16.99$ & 5 & 9.70 & CED II \\
\hline & & $17.00-18.49$ & 8 & 25.81 & CED I \\
\hline & & $18.50-24.99$ & 15 & 48.39 & Normal \\
\hline & & Total & 31 & 100.0 & \\
\hline & \multirow[t]{6}{*}{7} & $<16$ & 2 & 4.76 & CED IIII \\
\hline & & $16.00-16.99$ & 3 & 7.14 & CED II \\
\hline & & $17.00-18.49$ & 10 & 23.81 & CED I \\
\hline & & $18.50-24.99$ & 26 & 61.90 & Normal \\
\hline & & $>25.00$ & 1 & 2.39 & Over Weight \\
\hline & & Total & 42 & 100.0 & \\
\hline & \multirow[t]{5}{*}{8} & $<16$ & 1 & 2.27 & CED IIII \\
\hline & & $17.00-18.49$ & 2 & 4.55 & CED I \\
\hline & & $18.50-24.99$ & 35 & 79.55 & Normal \\
\hline & & $>25.00$ & 6 & 13.63 & over Weight \\
\hline & & Total & 44 & 100.0 & \\
\hline & \multirow[t]{4}{*}{9} & $17.00-18.49$ & 1 & 2.44 & CED I \\
\hline & & $18.50-24.99$ & 34 & 82.93 & Normal \\
\hline & & $>25.00$ & 6 & 14.63 & over Weight \\
\hline & & Total & 41 & 100.0 & \\
\hline & \multirow[t]{3}{*}{10} & $18.50-24.99$ & 29 & 58 & Normal \\
\hline & & $>25.00$ & 21 & 42 & Over Weigh \\
\hline & & Total & 50 & 100 & \\
\hline \multirow[t]{23}{*}{ Female } & \multirow[t]{6}{*}{6} & $<16$ & 10 & 22.73 & CED IIII \\
\hline & & $16.00-16.99$ & 5 & 11.36 & CED II \\
\hline & & $17.00-18.49$ & 13 & 29.55 & CED I \\
\hline & & $18.50-24.99$ & 15 & 34.09 & Normal \\
\hline & & $>25.00$ & 1 & 2.27 & Over Weigh \\
\hline & & Total & 44 & 100.0 & \\
\hline & \multirow[t]{5}{*}{7} & $<16$ & 3 & 6.67 & CED IIII \\
\hline & & $16.00-16.99$ & 3 & 6.67 & CED II \\
\hline & & $17.00-18.49$ & 15 & 44.44 & CED I \\
\hline & & $18.50-24.99$ & 24 & 53.33 & Normal \\
\hline & & total & 45 & 100.0 & \\
\hline & \multirow[t]{4}{*}{8} & $17.00-18.49$ & 5 & 10.87 & CED I \\
\hline & & $18.50-24.99$ & 36 & 78.26 & Normal \\
\hline & & $>25.00$ & 5 & 10.87 & over Weight \\
\hline & & Total & 46 & 100.0 & \\
\hline & \multirow[t]{5}{*}{9} & $<16$ & 1 & 2.5 & CED III \\
\hline & & $17.00-18.49$ & 3 & 7.5 & CED I \\
\hline & & $18.50-24.99$ & 30 & 75 & Normal \\
\hline & & $>25.00$ & 6 & 15 & over Weight \\
\hline & & Total & 40 & 100.0 & \\
\hline & \multirow[t]{3}{*}{10} & $18.50-24.99$ & 8 & 23.53 & Normal \\
\hline & & $>25.00$ & 26 & 76.47 & overWeight \\
\hline & & Total & 34 & 100.0 & \\
\hline
\end{tabular}

CED III Category: Severely undernourished CED II Catetory :ModeratelyUndernouished CED I Category : Midly undernourished 
categories of chronic energy deficiency categories and the frequencies are presented in table 5. The frequency of children falling in the severely under-nourished (CED III category) varies from $2.27 \%$ at 8 years to $9.7 \%$ at 6 years among boys. Among girls it ranges from $2.5 \%$ at 9 years to $22.73 \%$ at 6 years. The same trend has been observed among the children of 7 years, where girls showed higher proportion $(6.67 \%)$ compared to that of boys $(4.76 \%)$. Only $2.27 \%$ of boys in the 8 years and $2.5 \%$ of girls in 9 years age group fall in the CED- III, severely undernourished category in the higher age groups. The frequency of children, whose body mass index range from 16.0 to 16.99 is higher among boys $(16.13 \%)$ than that of girls $(11.36 \%)$ in the 6 years age and all fall in the moderately undernourished category -CED-II. Lower proportions of moderately undernourished children, $7.14 \%$ of boys and $6.67 \%$ of girls are found in 7 years age group. The frequency of mildly undernourished children ( CED- I category) whose body mass index range from 17.00 to 18.49 is high among the boys aged 8 years $(79.55 \%)$ followed by 6 years ( $25.81 \%$ ) and 7 years (23.81\%), while a small proportion $(2.44 \%)$ of boys in the age group of 9 years fall in the above category of undernourished. The proportion of mildly undernourished (category CED I) girls are high at younger ages $(29.55 \%$ at 6 years and $33.33 \%$ at 7 years) but with small proportions at 8 years $(10.87 \%)$ and 9 years $(7.5 \%)$. Most of the Lambadi boys and girls fall into the normal category of body mass index with varying proportion in different age groups (Table 5). The proportion of children possessing over weight is high in older ages compared to younger age groups. The mean body mass index of Lambadi boys show higher values than that of girls in 6 to 9 years age groups. But girls record higher mean body mass index value at 10 years than that of boys. It is evident that both boys and girls have gained in body mass indices as the age advances (Table 6).

Weight Deficit Classification: The data on body weight of the Lambadi children are classified based on the modified Gomez et al. (1956) classification as proposed by Vishveshwara Rao (1996). The mean weight of NCHS table for each age and sex is taken as the standard weight for classifying into different grades of weight for each age group (Table 7). In the total Lambadi girl sample, $2.3 \%$ in 6 years and $2.5 \%$ in 9 years
Table 6: Statistical constants of body mass indices of Lambadi children

\begin{tabular}{llcc}
\hline $\begin{array}{l}\text { Age group } \\
\text { (years) }\end{array}$ & $\begin{array}{l}\text { Statistical } \\
\text { Constants }\end{array}$ & Male & Female \\
\hline 6 & N & 31 & 44 \\
& Mean & 18.26 & 17.72 \\
& SD & 2.22 & 3.04 \\
7 & SE Mean & 0.4 & 0.46 \\
& N & 42 & 45 \\
& Mean & 18.85 & 18.78 \\
& SD & 2.14 & 2.13 \\
8 & SE Mean & 0.33 & 0.32 \\
& N & 44 & 46 \\
& Mean & 21.63 & 21.34 \\
9 & SD & 2.58 & 2.92 \\
& SE Mean & 0.39 & 0.43 \\
& N & 41 & 40 \\
\multirow{4}{*}{10} & Mean & 22.13 & 21.93 \\
& SD & 2.9 & 3.28 \\
& SE Mean & 0.45 & 0.52 \\
& N & 50 & 34 \\
& Mean & 24.77 & 26.56 \\
& SD & 2.72 & 2.91 \\
& SE Mean & 0.38 & 0.5 \\
\hline
\end{tabular}

are placed in grade IV category of malnutrition according to weight deficit for that age. Among the boys $2.3 \%$ in 8 years, $7.3 \%$ in 9 years and $2.0 \%$ in 10 years are placed in grade III malnutrition category. Whereas among the girls $15.0 \%$ in 9 years and $2.9 \%$ in 10 years are grouped in the grade III malnutrition category. Boys grouped under grade II category of malnutrition show the highest frequency $39.0 \%$ at 9 years followed by $34.0 \%$ at 10 years, $13.6 \%$ at 7 years, $21.4 \%$ at 8 years and $6.5 \%$ at 6 years. Girls grouped under grade II category of malnutrition record the highest frequency $28.3 \%$ at 8 years followed by $25.0 \%$ at 9 years, $20.6 \%$ at 10 years, $15.9 \%$ at 6 years and $13.3 . \%$ at 7 years. Boys grouped in grade I category of malnutrition show the highest frequency at 7 years $(52.4 \%)$, followed by $46.0 \%$ at 10 years, $45.5 \%$ at 8 years, $39 \%$ at 9 years and $35.5 \%$ at 6 years. Girls grouped under grade I category of malnutrition record the highest frequency at 10 years $(52.9 \%)$, followed by $48.9 \%$ at 7 years, $2.5 \%$ at 9 years, $41.3 \%$ at 8 years and $27.3 \%$ at 6 years. Boys with normal body weight as per the NCHS standards show the highest frequency $(58.1 \%)$ at 6 years, followed by $38.6 \%$ at 8 years, $26.2 \%$ at 7 years, $18.0 \%$ at 10 years and $14.6 \%$ at 9 years. Girls grouped under normal category show the highest proportion $(54.5 \%)$ at 6 years, followed by $37.8 \%$ at 7 years, $30.4 \%$ at 8 years, $23.5 \%$ at 10 years and $15.0 \%$ at 9 years. Majority of the Lambadi boys and girls are found to be having normal weight at 6 years of age. 
Table 7: Weight deficit classification of the Lambadi children

\begin{tabular}{|c|c|c|c|c|c|c|c|c|c|}
\hline \multirow[t]{2}{*}{ Ages } & \multicolumn{4}{|c|}{ Males } & \multicolumn{4}{|c|}{ Females } & \multirow[t]{2}{*}{ Grades/Categories } \\
\hline & \multicolumn{2}{|l|}{$\begin{array}{c}\text { Standard } \\
W t \quad(k g .)\end{array}$} & \multirow[t]{2}{*}{$F$} & $\%$ & \multicolumn{2}{|c|}{$\begin{array}{c}\text { Standard } \\
W t(k g .)\end{array}$} & \multirow{2}{*}{$\begin{array}{r}f \\
1\end{array}$} & $\%$ & \\
\hline \multirow[t]{5}{*}{6} & $50 \%$ of 22 & 11 & & - & $50 \%$ of 21.6 & 10.8 & & 2.3 & G-IV malnutrition \\
\hline & $60 \%$ & 13.2 & - & - & $60 \%$ & 12.96 & - & - & G-III malnutrition \\
\hline & $70 \%$ & 15.4 & 2 & 6.5 & $70 \%$ & 15.12 & 7 & 15.9 & G-II malnutrition \\
\hline & $80 \%$ & 17.6 & 11 & 35.5 & $80 \%$ & 17.28 & 12 & 27.3 & G-I malnutrition \\
\hline & $80+\%$ & 17.6 & 18 & 58.1 & $80+\%$ & $17.28+$ & 24 & 54.5 & Normal \\
\hline \multirow[t]{5}{*}{7} & $50 \%$ of 24.7 & 12.35 & - & - & $50 \%$ of 24.2 & 12.1 & - & - & G-IV malnutrition \\
\hline & $60 \%$ & 14.82 & - & - & $60 \%$ & 14.52 & - & - & G-III malnutrition \\
\hline & $70 \%$ & 17.29 & 9 & 21.4 & $70 \%$ & 16.94 & 6 & 13.3 & G-II malnutrition \\
\hline & $80 \%$ & 19.76 & 22 & 52.4 & $80 \%$ & 19.36 & 22 & 48.9 & G-I malnutrition \\
\hline & $80+\%$ & 19.76 & 11 & 26.2 & $80+\%$ & $19.36+$ & 17 & 37.8 & Normal \\
\hline \multirow[t]{5}{*}{8} & $50 \%$ of 27.8 & 13.9 & - & - & \multicolumn{3}{|c|}{$50 \%$ of 27.8613 .8} & - & G-IV malnutrition \\
\hline & $60 \%$ & 16.68 & 1 & 2.3 & $60 \%$ & 16.56 & - & - & G-III malnutrition \\
\hline & $70 \%$ & 19.46 & 6 & 13.6 & $70 \%$ & 19.32 & 13 & 28.3 & G-II malnutrition \\
\hline & $80 \%$ & 22.24 & 20 & 45.5 & $80 \%$ & 22.08 & 19 & 41.3 & G-I malnutrition \\
\hline & $80+\%$ & 22.24 & 17 & 38.6 & $80+\%$ & $22.08+$ & 14 & 30.4 & Normal \\
\hline \multirow[t]{5}{*}{9} & $50 \%$ of 31.2 & 15.6 & - & - & $50 \%$ of 31.4 & 15.7 & 1 & 2.5 & G-IV malnutrition \\
\hline & $60 \%$ & 18.72 & 3 & 7.3 & \multirow{3}{*}{$50 \%$} & 18.84 & 6 & 15 & G-III malnutrition \\
\hline & $70 \%$ & 21.84 & 16 & 39 & & 21.98 & 10 & 25 & G-II malnutrition \\
\hline & $80 \%$ & 24.96 & 16 & 39 & & 25.12 & 17 & 42.5 & G-I malnutrition \\
\hline & $80+\%$ & 24.96 & 6 & 14.6 & $80+\%$ & $25.12+$ & 6 & 15 & Normal \\
\hline \multirow[t]{5}{*}{10} & $50 \%$ of 33.7 & 16.85 & - & - & \multirow[t]{5}{*}{$50 \%$} & 17.6 & - & - & G-IV malnutrition \\
\hline & $60 \%$ & 20.22 & 1 & 2 & & 21.12 & 1 & 2.9 & G-III malnutrition \\
\hline & $70 \%$ & 23.59 & 17 & 34 & & 24.64 & 7 & 20.6 & G-II malnutrition \\
\hline & $80 \%$ & 26.96 & 23 & 46 & & 28.16 & 18 & 52.9 & G-I malnutrition \\
\hline & $80+\%$ & 26.96 & 9 & 18 & & $28.16+$ & 8 & 23.5 & Normal \\
\hline
\end{tabular}

Where as most of the boys and girls in 9 to 10 years are placed in the grade-I category of malnutrition. A negligible number of girls are grouped in the grade IV category of malnutrition, as per the weight deficit for that age.

Height Deficit Classification: Height deficit gives a picture of the past nutritional status. It is a reflection at the availability of nutrients to the body over a period of time. If the nutrients are inadequate the individual will have stunted growth. The data on stature of Lambadi children is grouped into categories of nutritional Vishveshwara Rao's the height deficit classification using NCHS standards for age and sex. The mean height of boys and girls in different age groups depicted in NCHS (Table 8) (Vishveshwara Rao 1996), have been taken as the standard height for that age and accordingly the Lambadi children are grouped into categories of poor, mild retardation and normal. The individual child having height above the NCHS standard height for that age and sex are grouped under the above normal category.

The distributions of various categories of height deficit classification of the Lambadi children are presented in table 8 . The lowest and the highest frequencies of mild retardation range in between $2.4 \%$ to $22.0 \%$ among boys and in between $6.7 \%$ to $27.5 \%$ among girls at 7 years and 9 years respectively. While lower proportions of mild retardation are recorded in other age groups, i.e. $6.5 \%$ to $8.0 \%$ among boys at 6 and 10 years respectively and $6.5 \%$ to $8.8 \%$ among girls at 8 and 10 years respectively. The Lambadi girls register higher frequencies (87\% to $88.4 \%$ ) in the normal category of height deficit classification than that of boys ( 70.5 to $85.7 \%$ ) at 7 and 8 years (Table 8 ), while the trend is reversed at 9 and 10 years, where boys record higher proportions ( $73.1 \%$ to $90.0 \%$ ) than that of girls $(65.0 \%$ to $85.3 \%)$. The frequency of boys with normal height varied from $54.8 \%$ at 6 years to $90 \%$ at 10 years, whereas the frequency of girls with normal height ranges from $65.0 \%$ at 9 years to $88.4 \%$ at 7 years. More than 100 percent height as per the NCHS standards for each age and sex treated as above normal has been observed among boys and girls in all ages, with varied frequencies. The highest frequency for the above normal category is observed among boys and girls of 6 years age. The proportion of above normal children for height decreases with advancing age in both boys and girls (Table 8). 
Table 8: Height deficit classification of the Lambadi children

\begin{tabular}{|c|c|c|c|c|c|c|c|c|c|}
\hline \multirow[t]{2}{*}{$\operatorname{Age}(\mathrm{s}$} & \multicolumn{2}{|c|}{ Standard Ht $(\mathrm{cms})$} & \multicolumn{2}{|c|}{ Males } & \multirow{2}{*}{\multicolumn{2}{|c|}{ Standard Ht (cms.) }} & \multicolumn{2}{|c|}{ Females } & \multirow[t]{2}{*}{ Categories } \\
\hline & & & $f$ & $\%$ & & & $f$ & $\%$ & \\
\hline \multirow[t]{4}{*}{6} & $80 \%$ of 118.6 & 94.88 & - & - & $80 \%$ of 117.8 & 94.24 & - & - & Poor \\
\hline & $90 \%$ & 106.74 & 2 & 6.5 & $90 \%$ & 106.02 & - & - & Mild retardation \\
\hline & $100 \%$ & 118.6 & 17 & 54.8 & $100 \%$ & 117.8 & 32 & 72.7 & Normal \\
\hline & $100+$ & $118.6+$ & 12 & 38.7 & $100+$ & $117.8+$ & 12 & 27.3 & Above Normal \\
\hline \multirow[t]{4}{*}{7} & $80 \%$ of 124.5 & 99.6 & - & - & $80 \%$ of 123.5 & 98.8 & - & - & Poor \\
\hline & $90 \%$ & 122.05 & 1 & 2.4 & $90 \%$ & 111.15 & 3 & 6.7 & Mild retardation \\
\hline & $100 \%$ & 124.05 & 36 & 85.7 & $100 \%$ & 123.5 & 38 & 88.4 & Normal \\
\hline & $100+$ & $124.05+$ & 5 & 11.9 & $100+$ & $123.5+$ & 4 & 8.9 & Above Normal \\
\hline \multirow[t]{4}{*}{8} & $80 \%$ of 130.0 & 104 & - & - & $80 \%$ of 129.4 & 103.52 & - & - & Poor \\
\hline & $90 \%$ & 117 & 3 & 6.8 & $90 \%$ & 116.46 & 3 & 6.5 & Mild retardation \\
\hline & $100 \%$ & $130+$ & 31 & 70.5 & $100 \%$ & 129.4 & 40 & 87 & Normal \\
\hline & $100+$ & $130+$ & 10 & 22.7 & $100+$ & $129.4+$ & 3 & 6.5 & Above Normal \\
\hline \multirow[t]{4}{*}{9} & $80 \%$ of 135.5 & 108.4 & - & - & $80 \%$ of 135.5 & 108.4 & - & - & Poor \\
\hline & $90 \%$ & 121.95 & 9 & 22 & $90 \%$ & 121.95 & 11 & 27.5 & Mild retardation \\
\hline & $100 \%$ & 135.5 & 30 & 73.1 & $100 \%$ & 135.5 & 26 & 65 & Normal \\
\hline & $100+$ & $135.5+$ & 2 & 4.9 & $100+$ & $135.5+$ & 3 & 7.5 & Above Normal \\
\hline \multirow[t]{4}{*}{10} & $80 \%$ of 140.2 & 122.16 & - & - & $80 \%$ of 140.9 & 112.72 & - & - & Poor \\
\hline & $90 \%$ & 126.18 & 4 & 8 & $90 \%$ & 126.81 & 3 & 8.8 & Mild retardation \\
\hline & $100 \%$ & 140.2 & 45 & 90 & $100 \%$ & 140.9 & 29 & 85.3 & Normal \\
\hline & $100+$ & $140.2+$ & 1 & 2 & $100+$ & $140.9+$ & 2 & 5.9 & Above Normal \\
\hline
\end{tabular}

\section{CONCLUSION}

The present study of the Lambadi children shows that they are tall in stature and have normal weight compared to the results reported by ICMR (1972). The growth trends of anthropometric traits among the Lambadi children are in close agreement with several studies in human populations reported by Eveleth and Tanner (1976). The body mass index reveals that most of the Lambadi children have normal body weight. The children fall short of the standards of height and weight as per NCHS for their respective age in both boys and girls. The results of the present study are comparable with the Indian boys and girls surveyed by ICMR (1972).

The various clinical signs observed among the Lambadi children indicate that they have vitamin-A, vitamin-B and vitamin-C deficiencies. They are also prone to various diseases due to unhygienic conditions in the areas of their habitation. Their parents' lack of education about the nutritional value affected their children growth. The medical and paramedical health institutions are dysfunctioning to provide health care facilities to the people residing in the tandas. Among the children measles, an epidemic disease is not identified during the survey, whereas cent percent polio vaccination is noticed. Diseases like Tuberculosis Malaria and Goiter are not found. Very few Lambadi children are severely under- nourished or malnourished in different age groups.

\section{REFERENCES}

Basu A 1999. Anthropometry, finger dermatoghyplics and blood groups of the Lambadi of Andhra Pradesh. In: TB Subba (Ed.). Wonder that is Culture. New Delhi: Mittal publication, pp. 149-162.

Census of India 1961. Vol.1, Monograph Series, Part V.B, (IV), Lambadi (A Scheduled tribe of Andhra Pradesh). A.M. Kurup, B.K.Roy Burman (Eds.). New Delhi: Manger of publications.

Eveleth PB, Tanner JM 1976. World Wide Variation in Human Growth. Cambridge: Cambridge University press.

Gomez F, Galvan R, Frank S, Cravioto J, Chavez R, Vasquiz $\mathrm{J}$ 1956. Mortality in Second and Third Degree Malnutrition. J Trop Paediatr, 2: 77.

ICMR 1972. Growth and Physical development of Indian Infants and Children. Technical Report series No.18 New Delhi: Indian Council of Medical Research.

Kaul SS, Nyamonogo IK 1990. Ecology, Growth and Maturation Status. New Delhi: Ashish Publishing House, pp.1-210.

National Center for Health Statistics 1970. Height and Weight of Children .United States Series No.11: 104 -124, U.S.A: Department of Health, Education and Welfare.

Rao BD, Busi BR 1995. Growth progression and maturational sequence among Savara tribal boys of Andhra Pradesh, India. J Hum Ecol, 6: 89-86.

Rao BD, Busi BR 1996. Patterns of physical growth and maturational sequence among Chenchu tribal boys of Andhra Pradesh, Bio-nature, 15: 11-18.

Rao BD, Busi BR 1997. A study of physical growth maturational sequence among Jatapu tribal girls of Andhra Pradesh, India. J Hum Ecol, 8: 355-359 
Rao BD, Busi BR 1997. A study of growth in physical and physiological variables among Koya Dora tribal boys of Andhra Pradesh, India. J Hum Ecol, 7: 1-3.

Rao BD, Busi BR 1999. Growth progression in physical and physiological variables among Porja tribal boys of Visakhapatnam District, Andhra Pradesh, India. South Asian Anthropologist, 20: 35-42.

Saheb SY, Naik VS 1983. Inbreeding and marital distance among the Banjara tribe of Andhra Pradesh. Indian Anthropologist, 13: 55-60

Saheb SY, Rajendra Prasad M 2007. Growth and development of the Lambadi children of Nalgonda district of Andhra Pradesh: Bio-Cultural perspective. Kolkata: Anthropological Survey of India, (in press).

Singh IP, Bhasin MK 1968. Anthropometry. Delhi: Bharti Bhawan.

Singh KS 1993. The Scheduled Tribes, People of India, National Series, Vol-.III, Delhi: Oxford University Press.
Tanner JM 1964. Human growth and constitution In: GA Harrison, JS Weiner, JM Tanner, NA Barnicot (Eds.): Human Biology. London: Oxford University Press, pp. 299-385.

Tanner JM 1978. Foetus to Man: Physical Growth from Conception to Maturity. Massachusetts: Harvard University press.

Vishweswara Rao K 1996. Bio-Statistics. New Delhi: Jaypee Brothers-Medical Publishers. pp. 384-394

Weiner JS, Lourie JA 1969. Human Biology: A Guide to Field Methods. I.B.P. Hand Book No.9, Oxford: Blackwell Scientific Publications,

WHO 1995. Physical status: The use and Interpretation of Anthropometry, Report of a W.H.O. Expert committee, Technical Report Series, No.854, Geneva: WHO

WHO 2000. Obesity: Preventing and Managing the Global Epidemic W.H.O. Technical Report Series, No. 894, Geneva: WHO. 